\title{
EQUIPMENT INVESTMENTS AND GROWTH NEXUS - EVIDENCE FROM SOCIALIST AND TRANSITION CROATIA
}

\author{
Marinko Škare', Dean Sinković ${ }^{2}$ \\ Department for Economics and Tourism "Dr. Mijo Mirković", Juraj Dobrila University of Pula, \\ Preradovićeva 1/1, 52100 Pula, Croatia \\ E-mails: ${ }^{1}$ mskare@unipu.hr (corresponding author); ${ }^{2}$ ssinkov@unipu.hr
}

Received 27 October 2011; accepted 12 May 2012

\begin{abstract}
New growth theories during the 1990s stress the importance of exploring a link between investments and growth. Using standard growth equations, we look into the correlation between investment in technical structure and growth in Croatia for two periods - socialist (1960-1989) and transition (1990-2009). Results suggest that equipment investments can boost growth rates through total factor productivity (TFP). This is consistent with the work of De Long and Summers (1991, 1992, 1993, 1994) and Temple (1998). In Croatia the equipment investments - growth link appears to be stronger than the structure investment - growth link for both periods. We also find a strong positive correlation between human capital and growth. Tests confirm the consistency and robustness of the regression results, suggesting inclusion of new variables in standard growth models. The structure of technical investments, real capital stock (not proxies) and estimated human capital stock (not schooling proxies) should have an important role in explaining international growth differences.
\end{abstract}

Keywords: economic growth, capital accumulation, structure of investments, Equipment stock, transition.

Reference to this paper should be made as follows: Škare, M.; Sinković, D. 2012. Equipment investments and growth nexus - evidence from socialist and transition Croatia, Technological and Economic Development of Economy 18(3): 504-528.

JEL Classification: G31, O11, O16, O47, R11, P24.

\section{Introduction}

Economic growth has become one of the most dynamic fields of research in economics through which many theories have tried to explain why some countries grow faster than others. Capital accumulation has always been the vital factor in GDP growth; however, its role in economic growth theory has been changing over time. 
The recent literature in economic growth argues that allocation efficiency of investment is more important than the level of investment. This argument leads to the question - are investments being allocated in the most productive and efficient way? New growth theories emerged during 1990s leading to investigation of the link between different types of investments and GDP growth. This line of thought was first addressed in the work of Mankiw et al. (1992) with a human capital augmented Solow model. They pointed out that accumulation of capital, with an emphasis on human capital, results in higher social rates of returns than the one explained by the conventional Solow model (Ding, Knight 2009). De Long and Summers $(1991,1992,1993,1994)$ published a series of papers investigating the relationship between the different components of investment and economic growth and concluded that equipment investments play a more important role in lifting output growth than structure investments. Their main argument was that structures cannot be exported and do not produce as strong externalities as equipment. With no ability to export and fewer abilities to create externalities, structure investments would have less influence on total factor productivity. Škare, Sinković (2007) use a De Long and Summers theoretical framework for the Republic of Croatia, for the period 1960-2006, and conclude the relationship between equipment investment and economic growth is stronger than between structure investments and growth.

We utilize the well-known standard approach introduced by Mankiw et al. (1992), and Benhabib and Spiegel (1994). We found a correlation between different components of investments (equipment, structure and human capital) and real GDP growth in Republic of Croatia for two periods - the pre-transition period (1960-1989) and the transition period (1990-2009). Similar to the work of Temple (1998) this paper improves previous works by using data on human capital (estimated stock of human capital) to control for the growth effect of education and technical structure of investments. Furthermore, to capture evolution and interdependence between variables, we use the Vector auto regression model (VAR) and the Vector error correction model (VECM). By means of quantitative (OLS, VAR and VECM) and qualitative analysis the authors have come to the following findings:

- The correlation coefficient between equipment investments and growth appears to be much higher than the one between structure investments and growth for both pretransition and transition period.

- There is a strong correlation between human capital and growth for the transition period.

- Equipment investments raise total factor productivity (correlation coefficient 0.42 ).

- Extensive growth pattern with high input expansion and low productivity growth has been the key factor accounting for the slow economic growth in Croatia.

- Equipment investment influence on TFP is stronger in an unstable Phillips curve environment than in a stable one (at least for Croatia).

We organize the paper as follows. Section I sets out the theoretical framework for this research. Section II sets out our analysis of the nature of growth in the Republic of Croatia. Sections III, IV and V carry out the data framework set out the model and interpret the empirical results for the pre-transition (1960-1989) and transition (1990-2009) periods. Section VI puts forward some concluding remarks. The formal statistical results are provided in an appendix. 


\section{Literature review on equipment and growth}

From a historical perspective both the theoretical and empirical literature emphasize capital accumulation as a key factor in determining long run economic performance. However, mainstream theories associated with Solow (1957) argue that macroeconomic policy cannot affect growth rates over the long term. Solow's conclusion was that capital accumulation would increase the growth rate in the short term, bringing countries to a higher level of income (transition effect), but would not generate any long term GDP growth because of the diminishing returns on capital. In other words capital deepening should be encouraged only because of the transition effect. Although some economists still accept this framework of economic growth, most of them find that the extended Solow version, given by Mankiw et al. (1992), provides more answers. The extended Solow model suggests that the conventional Solow model could explain most of the variations in GDP between countries, but it emphasizes the special role of human capital via education. MRW use the augmented Solow model with human capital to show that the social marginal product of human capital and physical capital is somewhat larger. However, the main focus of their model was on human capital with no special role for the disaggregated level of physical capital.

The theoretical basis for this research is driven from the findings of De Long and Summers (1991, 1992, 1993, 1994) and Temple (1998). De Long and Summers (henceforth DLS) stressed the main grounds on how equipment investments could be important for GDP growth (De Long, Summers 1991: 3-4):

- First, from a historical standpoint the application of capital-intensive technologies has played an important role in those countries that have grown rapidly in the last 100 years.

- Second, there must be strong positive externalities associated with equipment investments as technological progress (total factor productivity growth) is largely embodied in the form of new investment goods (Greenwood et al. 1996). Ninety-five percent of private-sector research and development in America is undertaken by the manufacturing sector, and within that the equipment sector accounts for more than half of all research and development (Summers 1990). Therefore, investigating the special role of equipment investments seems to be desirable.

- Third, countries that apply a government-led "developmental state" approach to structural changes invest more heavily, have lower equipment prices and enjoy more rapid economic growth (Hendricks 2000).

The aforementioned assumptions imply that more equipment investments mean faster technological progress generated through positive externalities when working with modern. As in the Solow model, the main generator of economic growth is technological progress; however, the same progress is not generated by 'manna from heaven' but is driven by the applications of suitable macroeconomic policies.

Research of De Long and Summers $(1991,1992)$ emphasizes the positive and significant correlation between the growth of GDP per worker and the share of real GDP devoted to equipment investments. The results of their cross section regression in a sample of 61 countries show that a 1 percentage point increase in equipment investments is estimated to increase the average annual GDP per worker by 0.223 percentage point per year. The difference in 
equipment investment in a statistical sense accounts for much of the growth performance for the sample countries. They found that countries with a high share of equipment investments grew extremely rapidly, even when controlling for a number of factors and no matter whether equipment investments were a result of high savings or low relative equipment prices. Japan achieved a growth rate edge of $2.2 \%$ per year from 1960 to 1985 relative to the average pattern. Conversely, Argentina has suffered a growth deficit of $2.1 \%$ per year. More than four fifth of this difference is accounted for by high or low equipment investments.

Soon after, De Long and Summers released a series of papers emphasizing how equipment investments yield important external benefits. Many economists started investigating this approach. Auerbach et al. (1993) found that the link between different components of investments and growth in the OECD countries is fully consistent with the Solow model. He stressed two main shortcomings in the approach of De Long and Summers; first De Long and Summers failed to conduct any statistical test of the Solow model, and second it fails to survive the test of robustness. In a 1998 paper Temple investigated the relationship between equipment investment and growth by using the MRW framework. His research improved the work of De Long and Summers and Auerbach by using a well-recognized and accepted theoretical framework, taking a more rigorous approach to outliers, using data on human capital, taking unobserved heterogeneity into account and by applying instrumental variables. He observes three different samples: first the 'non-oil' sample of developing and industrialized countries, second the 'non-oil' sample excluding OECD countries, and a third sample which includes the OECD countries. The results showed that equipment investment is weakly correlated with growth in the OECD sample but strongly correlated with the large group of developing countries, an outcome that is pretty much consistent with the De Long and Summers findings. Even so, a more interesting result was that the magnitude of the estimated returns on equipment investment was well over 50 percent and much higher than the estimated return on structure investments. Furthermore, Temple and Voth (1996) carried out a robust regression and concluded that the Solow model is strongly rejected for the poorest countries. Another important paper on this topic is Jones (1994) who suggested that there is a strong negative correlation between economic growth and the relative price of machinery. Significant doubt on the investment growth nexus remains between the positive causality supporters Barro (1991), De Long and Summers (1991, 1992), Levine and Renelt (1992) and critics Blomstrom, Lipsey and Zejan (1993). Sufian (2010) examines the impact of mergers and acquisitions on the technical efficiency of the banking sector. Dulleck and Foster (2008) show that link between equipment investment and growth is lower or negative in countries with low human capital stock. Benhabib and Spiegel (2005) support the thesis advanced by Dulleck and Foster (2008) finding that critical level of human capital is needed to boost total productivity growth. Greenwood and Krusell (2007) argue that to investigate the investment-growth link quantitative theory should be preferred to the traditional growth accounting approach. Del Rio (2010) shows that faster investment - specific disembodied technological progress reduces job creation and consequently economic growth in the long-run. Field (2007) points to the absence of evidence supporting the existence of positive systematic relationship between rates of equipment investments and total factor productivity growth. 
Tridico (2007) investigates the relationship between the human development process and economic growth in transitional countries, finding a Granger causality relationship between the two variables. Tvaronavičius and Tvaronavičienè (2008) find a relationship between fixed investment and economic growth in Lithuania. Tvaronavičienè, Grybaite and Korsakiene (2008) investigate the inflow of FDI into Lithuania as a possible financial source for fixed investments [stressing out main FDI determinants]. Tvaronavičienè and Grybaitè (2007) also studied particular aspects of development and determinants of FDI for the Lithuanian economy by investigating how different levels of penetration of foreign capital into certain economic activities relate to the country's economic growth. Tvaronavičienè (2006) investigates the main driving forces of economic growth in Lithuania, giving special attention to the roles of FDI and international trade.

\section{Nature of economic growth in Croatia}

Investigation of the key factors of economic growth in Republic of Croatia should generate valuable insights for policy makers wanting to establish an efficient macroeconomic framework in order to improve the economy's productive and competitive capacity in transition or former transitional countries. This will positively affect GDP, employment and other important economic variables in the long run.

Škare (2001) analysed the nature of economic growth in Croatia for the pre-transition period (1950-1990). This research showed that more than 50 percent of the GDP growth was generated through the use of labor and 44 percent using capital. The overall growth record for Croatia represented the classical growth theory framework emphasizing the key growth sources - physical capital and labor force (Table 1). Human capital and technological progress generated only a minor impact on output because of the disinvestment process in R\&D and education. Despite a solid average growth rate of 2.67 percent over 1960-2009, the speed of the Croatian economy's convergence towards the EU still remained slow.

Table 1. Sources of growth in Republic of Croatia (1960-2009)

\begin{tabular}{lcccc}
\hline & $\begin{array}{c}\text { Percentage } \\
\text { distribution } \\
\text { with capital } \\
\text { stock }\end{array}$ & $\begin{array}{c}\text { Average } \\
\text { annual } \\
\text { growth } \\
\text { rate }\end{array}$ & $\begin{array}{c}\text { Percentage } \\
\text { distribution } \\
\text { with investment } \\
\text { (I/GDP) }\end{array}$ & \\
\hline Real output growth & 100.0 & 2.67 & 100.0 & Real output growth \\
\hline Factors contributions: & & & & Factor contributions: \\
\hline $\begin{array}{l}\text { Capital (stock } \\
\text { measured) }(\alpha=0.11)\end{array}$ & 21.7 & 5.27 & 49.3 & $\begin{array}{l}(\alpha=0.25) \text { Capital } \\
\text { (I/GDP as proxy) }\end{array}$ \\
\hline Labor $(\delta=0.40)$ & 23.5 & 1.57 & 21.2 & $(\delta=0.36)$ Labor \\
\hline $\begin{array}{l}\text { Human capital } \\
(\beta=0.09)\end{array}$ & 15.7 & 4.65 & 13.9 & $(\beta=0.08)$ Human capital \\
\hline Technological progress & 39.1 & - & 14.2 & Technological progress \\
\hline
\end{tabular}

Source: Author's calculation 
Table 1 gives us estimated shares of capital ( $\alpha)$, human capital $(\beta)$ and labor $(\delta)$ in national income. Estimated factor shares are within expected ranges as suggested by theory (Solow growth model) and international research studies for development economies and countries in transition. The results in Table 1 indicate that the Solow model did not function well for the Croatian economy for the given period of time. The economic growth in Croatia was intensely generated by labor, contrary to the Solow doctrine that emphasized a negative relationship between population and GDP growth rates. Furthermore, technological progress had a minor impact on the real GDP growth rate. However, the reason for the second finding might be due to a poor depreciation policy and as mentioned, disinvested processes in R\&D. Dolenc et al. (2011) show that Croatia is classified among countries with high unemployment, low employment rate and higher tax wedge. They find a positive link between the tax wedge at different wage levels and the unemployment rate.

Table 2 shows that the investment share of GDP was strongly correlated with the GDP per capita growth rate for the same period of time. The correlation coefficient was even higher for human capital indicators (secondary and primary school enrolment) proving the main arguments from the extended Solow model.

Table 2. Growth characteristics for Croatia, 1960-1989

\begin{tabular}{lcc}
\hline \multicolumn{1}{c}{ Characteristics } & Overall average & Correlation with GDP growth rate \\
\hline Real per capita GDP growth 1960-1989 & 4.2 & 100,0 \\
\hline Investment share of GDP & 18.3 & 0.45 \\
\hline Government consumption share of GDP & 14 & 0.15 \\
\hline Inflation rate & 43.6 & -0.20 \\
\hline Exports as a share of GDP & 19.3 & 0.12 \\
\hline Imports as a share of GDP & 25.9 & 0.27 \\
\hline Secondary school enrolment rates 1960 & 34 & 0.83 \\
\hline Primary school enrolment rates 1960 & 78 & 0.50 \\
\hline Population growth & 0.4 & 0.24 \\
\hline Real per Capita GDP in 1960 & $2.324 \$$ & 0.20 \\
\hline
\end{tabular}

Source: Author's calculation

Having in mind that Croatia is a country in transition with a poor technical structure of investments (investing mainly in structures (roads, hotels, residential buildings and similar infrastructure)), with a low level of human capital investment, it is no wonder that the economic future in Croatia is problematic. The current technical composition of investment certainly does stimulate GDP, but with no meaningful economic impact in the long term (Figure 1). Large investments in equipment and human capital are needed to change the technical structure of investment and boost growth.

This paper improves on previous work on economic growth and equipment investment in Croatia (Škare, Sinković 2007). First we use data on human capital stock to control for the growth effect of education, extending the work of Mankiw, Romer, Weil and Temple and 


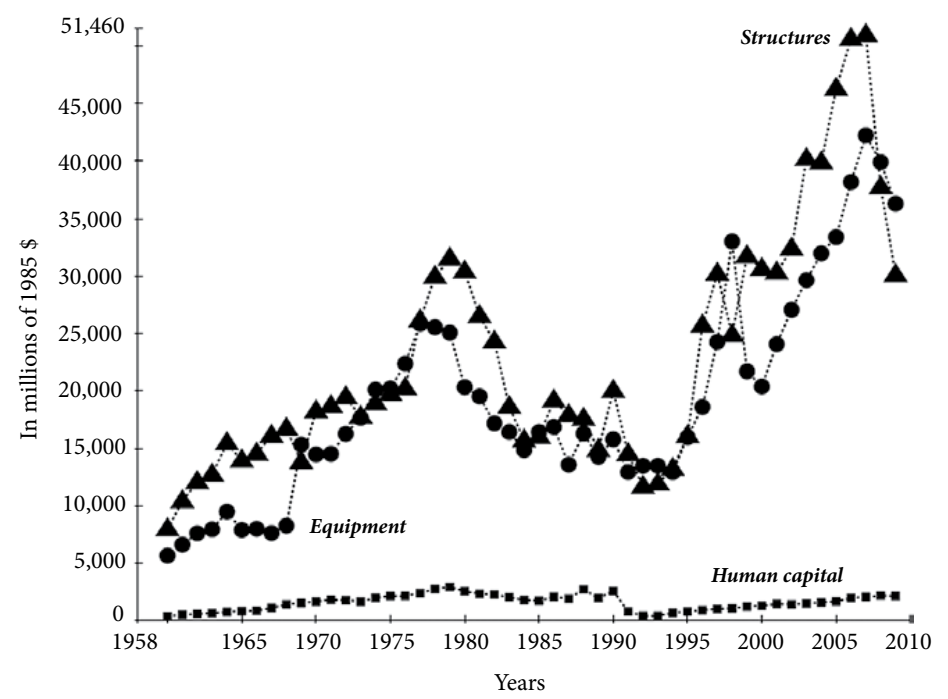

Fig. 1. Equipment, Structures and Human Capital stock in Croatia 1960-2009 (in 1985 thousands international \$). Source: Author's calculation based on the data from the Croatian statistical office

others, using proxies for human capital or capital stock. Then we carry on a separate research on the investment-growth nexus in the pre-transition (planned economy, 1960-1989) and post-transition (market economy, 1990-2009) periods.

A huge spike in structure investments in the transition period was due to large government spending in order to rebuild war-damaged regions and road infrastructure with the goal of stimulating the tourism sector. On the other hand, private sector investments were focused on building residential real estate infrastructure. At the same time, SMEs and industry sectors, which represent the key engines of equipment investments, were denied the needed financial support from both commercial and developmental-government banks.

One of the reasons for such a scenario might be the 'successful' privatization of the Croatian banking sector that took place soon after the end of the war. Since 2000 most of the transitional countries experienced large foreign investments in the banking sector that resulted in foreign bank ownership of most bank assets in all of the countries. By the end of 2000 almost 85 percent of the Croatian banking sector assets were controlled by foreign investors who indeed vastly improved the quality and performance of the financial services. However, when choosing to channel financial resources between a relatively risky SME sector and profitable and low risk household sector, Croatian private commercial banks have chosen the second. Rising from very low levels in 1999, household loans grew almost six times by 2008, reaching 35 percent of GDP - the highest level in all the transitional countries. In the same period, enterprise credit grew almost three times (see Table 3). Dolenc (2010) finds no important macroeconomic effects of privatization in the former transition country of Slovenia. 
Table 3. Loan Portfolio of the commercial banking sector in Croatia (1999-2008), in millions of KN

\begin{tabular}{lccccccccccc}
\hline & 1999 & 2000 & 2001 & 2002 & 2003 & 2004 & 2005 & 2006 & 2007 & 2008 & TOTAL \\
\hline Government & 2,990 & 4,102 & 4,100 & 6,700 & 8,547 & 9,031 & 12,758 & 14,517 & 14,316 & 21,495 & 98,557 \\
\hline $\begin{array}{l}\text { Financial } \\
\text { Institutions }\end{array}$ & 1,286 & 1,116 & 1,190 & 2,156 & 3,057 & 3,289 & 3,867 & 4,035 & 6,950 & 5,796 & 32,742 \\
\hline Enterprises & 24,889 & 24,986 & 32,393 & 41,695 & 45,269 & 49,590 & 58,670 & 75,070 & 83,324 & 94,114 & 530,001 \\
\hline Households & 17,925 & 21,570 & 28,464 & 41,111 & 52,587 & 62,652 & 75,713 & 92,682 & 109,545 & 122,742 & 624,991 \\
\hline Other & 0,700 & 0,582 & 0,514 & 0,788 & 0,734 & 0,703 & 0.948 & 1,470 & 2,134 & 2,510 & 10,135 \\
\hline TOTAL & 47,790 & 52,356 & 66,661 & 92,450 & 110,194 & 125,265 & 151,010 & 187,774 & 216,269 & 246,657 & 1296,43 \\
\hline
\end{tabular}

Source: Croatian National Bank (2009)

The ignorance toward the SMEs and industry sectors, the two sectors that represent the main driving forces of long term economic growth and development (innovations, technology transfer and new employment), created some serious socio-economic problems. Since Croatia's scarce financial resources have been channelled in a very poor manner, it resulted in inappropriate composition of investments. Yilmaz and Koyuncu (2010) show empirical evidence on negative relationship between foreign bank concentration and banking crises for transition countries. Perhaps the reason for banks' reluctance to lend to the Croatian industry sector might be a poor privatization and enterprise transition process. Croatian private banks decided to promote consumption spending instead of investment spending. Overall, huge lending boom in Croatia generated the following problems:

- Highly indebted households in which income has been nose diving ever since 2008 due to rising unemployment coming from the mix of poor economic policies and the global financial crisis.

- Poor composition of investments.

At the same time, the Croatian government channelled most of its resources toward building highways and other road infrastructure. Since most of those investments were financed by external borrowings, it represents another burden for Croatian economic performance. Therefore, Croatian economic growth was fueled by consumption spending (household loans spent mostly on real estate and imported goods) and government spending (structure investments) that might have very dangerous implications for the economy in the long run. In a situation when external debt has reached almost 100 percent of GDP and with inadequate levels of human capital and equipment investments, Croatia could face serious problems soon.

\section{Data and methodology}

In the study, we use several different approaches to estimate the equipment investment - growth nexus in Croatia. In the first part of the analysis we use a Cobb-Douglas production function to identify growth sources and total factor productivity (TFP) we need for further analysis. We use the Cobb-Douglas production function with capital, human capital and labor inputs.

$$
Y=A_{t} K_{t}^{\alpha} H_{t}^{\beta}\left(L_{t}\right)^{\delta}
$$


512 M. Škare, D. Sinković. Equipment investments and growth nexus - evidence from socialist ...

after taking logs and differencing,

$$
\frac{\dot{Y}}{Y_{t}}=\frac{\dot{A}}{A_{t}}+\alpha \frac{\dot{K}}{K_{t}}+\beta \frac{\dot{H}}{H_{t}}+\delta \frac{\dot{L}}{L_{t}}
$$

with: $K_{t}=$ Capital stock; $H_{t}=$ Human capital stock; $L_{t}=$ labor force and assuming $\alpha+\beta+\delta<1$ (decreasing returns to all capital as in Mankiw, Romer and Weil with no steady states). Rather than imposing the constant return to scale hypothesis (CRS), we tested the model under CRS assumption, and the results reject the CRS hypothesis, backing up the assumption of decreasing returns to scale.

A modified De Long and Summers (1991) model of the form

$$
Y=c+\beta_{E} i_{E}+\beta_{S} i_{S}+\delta G A P+\gamma L+\varepsilon
$$

with: $Y=$ real GDP growth rate; $i_{E}=$ investment share/GDP; $i_{S}=$ structure share/GDP; GAP = GDP gap; $L=$ labor force growth rate is used to analyze investment-specific productivity change to output growth in Croatia. Following the work of Benhabib and Spiegel (1994) we use the augmented Solow model to investigate the relationship between equipment investments and output in Croatia. The model as in Benhabib and Spiegel (1994) is presented in the following form:

$$
\Delta \log Y=\Delta \log A+\alpha \Delta \log E+\gamma \Delta \log S+\beta \Delta \log H+\theta \Delta \log L+\varepsilon_{t}
$$

with: $Y=$ Croatian gross domestic product (expressed in Geary - Khamis 1990 international prices \$, millions), (Geary 1958; Khamis 1972); A = technical progress (efficiency parameter); $E=$ investments in equipment (expressed in Geary - Khamis 1990 international prices \$, millions), (Geary 1958; Khamis 1972); $S$ = investments in structures (expressed in Geary - Khamis 1990 international prices \$, millions), (Geary 1958; Khamis 1972); H= human capital (expressed in Geary - Khamis 1990 international prices \$, millions), (Geary 1958; Khamis 1972); Labor = labor force; $\varepsilon_{t}=$ stationary disturbance term.

In his research, Temple (1998) uses a Cobb-Douglas production function similar to the one used in Mankiw, Romer and Weil (1992) in the form

$$
\begin{aligned}
& \ln \frac{Y_{t}}{L_{t}}-\ln \frac{Y_{0}}{L_{0}}=\theta \ln A_{0}+g t+\theta \frac{\alpha}{1-\alpha-\gamma-\beta} \ln s_{e}+\theta \frac{\beta}{1-\alpha-\gamma-\beta} \ln s_{s}+ \\
& \theta \frac{\delta}{1-\alpha-\gamma-\beta} \ln s_{h}-\theta \frac{(\alpha+\beta+\delta)}{1-\alpha-\gamma-\beta} \ln (n+g+\delta)-\theta \ln \frac{Y_{0}}{L_{0}}
\end{aligned}
$$

with standard notation.

Using Cobb-Douglas labor augmenting form

$$
Y=E^{\alpha} S^{\gamma} H^{\beta}(A L)^{1-\alpha-\gamma-\beta}
$$

or in terms of labor productivity

$$
y_{t}=e_{t}^{\alpha} s_{t}^{\gamma} h_{t}^{\beta} a_{t}^{1-\alpha-\gamma-\beta}
$$


with: $e_{t}=E$ (stock of equipment) $/ \mathrm{L} ; s_{t}=S$ (stock of structures) $/ \mathrm{L} ; h_{t}=H$ (human capital stock) $/ \mathrm{L}$ and $y_{t}=Y / L$ we derive the growth accounting equation (in terms of log differences) and productivity growth expressed as

$$
g_{y}=\alpha g_{e}+\gamma g_{s}+\beta g_{h}+(1-\alpha-\gamma-\beta) g_{a} .
$$

Because of the expected heterogeneity in the data we use also time series VAR and VECM approach to investigate the relationship between equipment investments and growth. To investigate the relationship between economic growth and physical capital at a disaggregated level (equipment and structures), labor and human capital, we use the time series approach by using the Vector autoregressive models (VARs). That way we want to examine the nature of the statistical causality between labor, human capital, equipment, structure investments and output with a particular insight on the equipment investments and output causality.

$$
\Delta y_{t}=a_{0}+\Gamma(L) \Delta y_{t-1}+\Pi y_{t-k}+\mu_{t}
$$

with: $y_{t}$ a vector of K observable endogenous variables (GDP, Equipment stock, Structure stock, Human capital stock, Labor force) and matrix of coefficient $\Gamma$; lag operator (L); П matrix of cointegrating vector and $\mu$ white noise process.

We use the macroeconomic time series data that often involve the unit root problem that could compromise the results of the Granger causality test. Therefore, we test the data for the existence of cointegration in order to see if the conventional granger form test has to be reparametrized. First we test how investments in Croatia affect output (do investments cause output, INV $\rightarrow$ GDP) and if a bilateral causality between investments and output exists, i.e. does output cause investments GDP $\rightarrow$ INV.

Before proceeding with the Granger causality test, we have to test the series for the nonstationarity (existence of unit root) with a standard stationarity test (results are reported in the appendix). To test for the stationarity and the impact of equipment investments on Croatian GDP we split the observation period in two: first one (1) denoting the pre-transition time (former socialist republic of Croatia) oriented toward a more planned economy, and second (2) the transition period after 1990 with Croatia moving toward a free market economy. The transition period was tested for the structural breaks in time series because of the war (1991-1995) and the need to (or not) introduce a dummy variable for the war. Tests performed on the data series suggest that the level data are non-stationary time series. Unit root tests show the existence of a unit root process proving non-stationarity between time series used in the model (see appendix). Appropriate transformation of the series before entering the OLS models was applied.

Data were obtained from the Statistical Yearbooks of Yugoslavia (1960-1990) and the Statistical Yearbooks of Croatia (1991-2009), and we calculated the series in 1985 dollars. For the methodology of human capital measurement in Croatia see Škare (2001). Additional data was obtained from Maddison $(2001,2003)$.

To uncover the truth we must go under the surface of the raw data and search for the hidden signals in the data. We use spectral density analysis to trace out possible quantitative relationships that may occur. First, we filter the "raw" data to detrend and smooth the original series by Fourier's transformation. Fourier's transformation procedure can be used only on the 
stationary data. To eliminate the possibility of the presence of non-periodic components in the series, we transform each of the input series (tapering, mean subtraction and detrending to get smoother spectrums and correct for the leakage problem) so we are cleared to proceed with the Fourier transformation.

$$
\begin{aligned}
& U(k)=\frac{1}{N} \sum_{j=0}^{N-1} u(j) e^{-i 2 \pi j k / N}, \\
& u(j)=\sum_{k=-[N / 2]}^{[N-1 / 2]} U(k) e^{i 2 \pi j k / N} .
\end{aligned}
$$

Spectral density estimation aloud to "scan" the general variance in the time series in terms of cycles that correspond to each signal frequency to identify sine and cosine functions over different frequencies that are more strongly correlated to the time series data. Extension of the single spectrum analysis is the cross-spectrum analysis for uncovering the correlation between two time series data at different frequencies. We are looking for correlated cyclical behaviour for investment/output. To decompose covariance of the time series data in frequency components (correlation analysis) we use several standard procedures ${ }^{1}$.

$$
\begin{gathered}
\Psi_{K}=\left\{\begin{array}{ll}
\tan ^{-1}\left(Q_{K} / C_{K}\right) & \text { if } Q_{K}>0, C_{K}>0 \\
\tan ^{-1}\left(Q_{K} / C_{K}\right)+\pi & \text { if } Q_{K}<0, C_{K}>0 \\
\tan ^{-1}\left(Q_{K} / C_{K}\right)-\pi & \text { if } Q_{K}<0, C_{K}<0
\end{array}\right. \text { Phase Spectrum (time-lag) } \\
X_{t}=a_{0}{ }^{x}+\sum_{K=1}^{q}\left(a_{K}^{x} \cos 2 \pi f_{K} t+b_{K}^{x} \sin 2 \pi f_{K} t\right) t=1, \ldots, \lambda \\
Y_{t}=a_{0}^{y}+\sum_{K=1}^{q}\left(a_{K}^{y} \cos 2 \pi f_{K} t+b_{K}^{y} \sin 2 \pi f_{K} t\right) \\
\hat{C}_{K}=\sum_{j=-p}^{p} w_{j}(R C)_{K+j} \quad \text { Cospectral density estimate } \\
\hat{K}_{12}(k)=\frac{\sqrt{\hat{C}_{12}(k)^{2}+\hat{Q}_{12}(k)^{2}}}{\sqrt{\hat{S}_{1}(k) \hat{S}_{2}(k)}} \text { Coherency spectrum (correlation coefficient) } \\
K_{K}=\frac{A^{2}{ }_{K}}{S_{K}^{x} S_{K}^{y}} \text { Squared coherency spectrum }\left(R^{2}\right)
\end{gathered}
$$

1 For technical detail and references see Bloomfield, P. 1976. Fourier analysis of time series. New York: John Wiley and Sons and Iacobucci, A., Spectral Analysis for Economic Time Series, OFCE Working Paper, N. 2003-07. 


$$
G_{K}=\left\{\begin{array}{l}
A_{K} / S_{K}^{x}\left(\text { gain of } Y_{t} \text { over } X_{t} \text { at } f_{K}\right) \\
A_{K} / S_{K}^{y}\left(\text { gain of } X_{t} \text { over } Y_{t} \text { at } f_{K}\right)
\end{array}\right. \text { Gain values (regression coefficient) }
$$

with Tukey-Hamming window (5) of the form

$$
\begin{aligned}
& W_{k}=0.54(D)_{p}\left(2 \pi f_{k}\right)+0.23 D_{p}\left(2 \pi f_{k}+\frac{\pi}{p}\right)+0.23 D_{p}\left(2 \pi f_{k}-\frac{\pi}{p}\right) \\
& \text { for } k=0, \ldots, p .
\end{aligned}
$$

Since we filter all the time series data we refer to the data used in the spectral analysis as detrended time series.

\section{Equipment investment growth nexus in socialist Croatia (1960-1989)}

Much theoretical and empirical research on the investment and long-term economic growth nexus has emerged since 1950. The Croatian experience could be valuable evidence for both theoretical and empirical economic knowledge. Our results can be of practical importance for countries similar to Croatia but also for all other economies. Our attempt to reveal the role of gross equipment investments for long-term economic growth in Croatia can provide useful knowledge on the investment - growth debate. Here we explore the role of equipment investment for future output growth in Croatia during the socialist and transition eras. Results can bring us closer to the answer about the causality between equipment investment and growth not just for Croatia. Comparing the results from both periods, we can assess the link between investments and growth for small, closed, socialist countries but also for small, open, market economies. In addition, we can search for the constraints that might arise in a state-planned economy and the importance of economy structure on the causality we wish to explore. This section introduces a new way of exploring the equipment investments - economic growth nexus by means of spectral density analysis. Causality between investment and growth is captured in the coherence spectrum, with statistical significance of a potential relationship offered through the square coherency spectrum.

Figure 2 displays a bivariate spectral analysis for equipment investment and output. The cospectral density plot (top left panel) is significant in the long run (after six years). Bilateral periodicity in the short run for equipment investment and output is not present. Movement between the two series in the long run is significant. In the phase spectrum plot (bottom right panel) we notice a most significant influence of fixed investment on output concentrated in the band $(8,30)$ years), supporting investment as a means of promoting growth in the long run. The chart points to a constant and significant long run relationship, while in the short run a volatile relationship appears. The coherence and squared coherence plot (top right panel) registers a maximum frequency domain correlation at 30 years, pointing out where to find a significant relation between investment and output (over the $(8,30)$ year's band). A strong correlation (ranging from $0.30-0.98$ ) with the $\mathrm{R}^{2}$ equal to an average value of 0.64 to a maximum of 0.98 is found in the observed band but also out of the band, suggesting that output can be expressed as a linear function of fixed investments. 
Cospectral Density X: Equipment Y: GDP No. of cases: 30

Hamming weghts: ,0357, 2411, 4464, 2411,

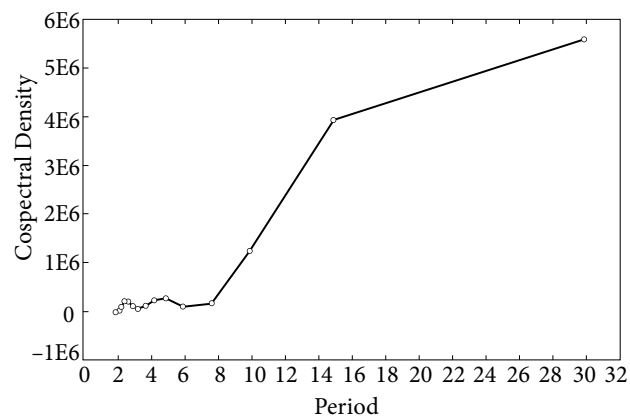

Gain of Y over X X: Equipment Y: GDP No. of cases: 30 Hamming weghts: ,0357, 2411, 4464, 2411, 0357

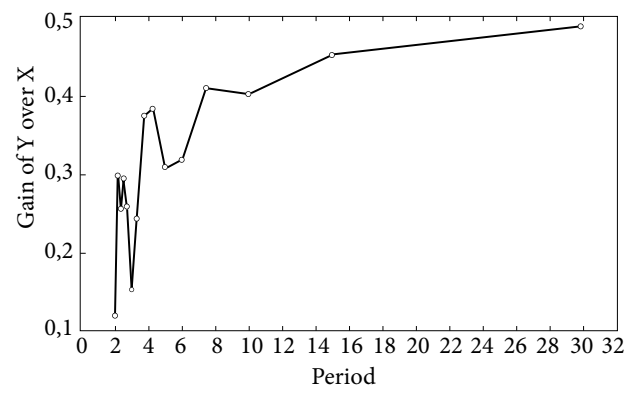

Squared Coherency X: Equipment Y: GDP No. of cases: 30 Hamming weghts: 0357,0357

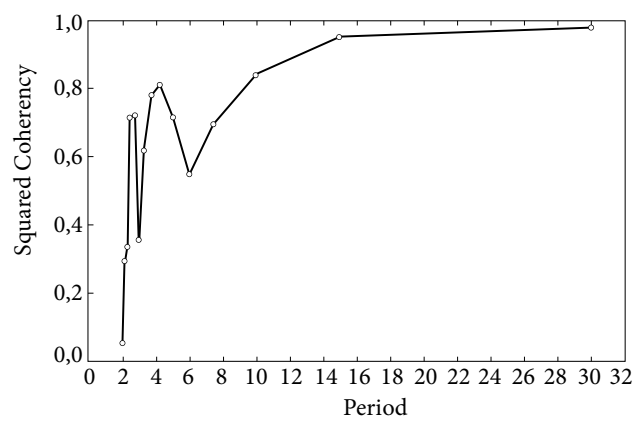

Phase Spectrum X: Equipment Y: GDP No. of cases: 30 Hamming weghts: $0357,2411,4464,2411,0357$

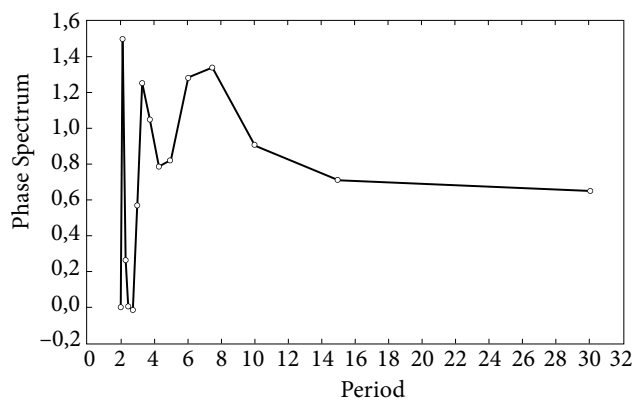

Fig. 2. Spectral and cross spectral analysis for equipment investments and growth (1960-1990). Source: Author's calculation

Notice that phase differences and amplitude ratios stay constant over a long frequency domain. A significant relationship between output and investment is also validated in average correlation parameters of Gain values (bottom left panel), supporting evidence of fixed investment output with a maximum gain value around the 30 years over the $(0,30)$ band period. The maximum gain value reaches 0.5 during the thirty-year period, suggesting a stronger impact of investment on output in the long run. The average gain value (regression coefficient) is 0.32 with the expected return $(0.32 \$)$ on fixed investments (1\$) supporting the importance of investment and capital accumulation in promoting economic growth, particularly in the long run. The estimated share attributed to equipment is much higher than expected by the traditional Solow model (0.04), showing that investments in equipment were an important source of growth in socialist Croatia. Results support the traditional view of the Solow model and the role of investments in capital stock accumulation. Investments in equipment seem to have particular importance for economic growth in socialist economies with high social returns to equipment investments (much more than predicted by the Solow model). The estimated share attributable to equipment matches the one identified by Temple and Voth (1996) for developing countries, which Croatia, in fact, was during the period 1960-1989, supporting his conclusion that investments in equipment are strongly correlated 
with growth for developing economies. We conclude that positive and important two-way causality runs between equipment investments and growth where a $1 \$$ increase in output leads to a $2.10 \$$ increase in capital stock. Using standard econometric methods, we examine the nexus between investment and growth once again and compare the results with the one obtained by cross-spectral analysis.

Table A1 show the test statistics for the Augmented Dickey Fuller and Phillip Perron unit root tests. The data series in level data thus demonstrates non-stationarity with the presence of the unit root. Both $\mathrm{ADF}$ and $\mathrm{PP}$ tests failed to reject the null hypothesis of non-stationarity, except for capital in ADF without trend and intercept. Both tests reveal that data series in the first difference are stationary with the unit root hypothesis rejected for the data in a first difference at the standard significance level. After ADF and PP tests rejected the unit root hypothesis pointing to non-stationarity in data, we tested the data for cointegration using the Johansen cointegration test (maximum eigenvalue and trace test). The plotted data of the series shows that all series are trend stochastic, so we use the Johansen cointegration test on series under a linear trend assumption and only intercept in the cointegration equations. Results of the cointegration trace test are presented in Table A2. The null hypothesis of no cointegration had to be rejected at the $5 \%$ confidence level tested against the $\mathrm{H} 1$ hypothesis of one cointegrating vector $(r=1)$. The data in the table show that trace test indicates one cointegrating vector with rank test (max eigenvalues) showing zero cointegrating relations (vectors). Following Engle and Granger (1987) after cointegration between data of order I(1) has been identified, we construct a Granger causality test for level VARs to test statistical causality between output, investments (in equipment and structure), labor and human capital. According to Engle and Granger, if two series are found to be integrated of order I(1) (tested with ADF and PP test) and cointegrated (we found one cointegrating vector), the standard Granger causality test applies.

Before testing for bi-directional feedback (Granger causality test) we first choose the optimal lag length by estimating VAR (2a-2e) model including all variables in levels (nondifferentiated data). To choose the optimal lag length we use AIC and SBC and FPE criteria (see Table A3 in appendix). The optimal lag selection results differ for various lag order tests. AIC, FPE and HQ test suggests four lag models while LR and SC suggest one lag model. Using BIC instead AIC we choose one lag model as optimal (according to SIC criteria in the appendix). For safety reasons, we checked the residual graph and residual autocorrelation, and both support the one lag model. To test for short run causality between dependent and independent variables, we run the Granger causality test. Results of the Granger causality test are presented in Table 4. We explore the possible existence of a systematic relationship between past values of equipment investment, structure investment, human capital, labor, output and future values of output. The test results support previous findings on the importance of equipment investments on economic growth in Croatia. From Table 4 we can see that the null hypothesis of no Granger causality between output and equipment investment is rejected at the 5 percent significance level. Data suggest a uni-directional relationship between output and equipment investments. 
518 M. Škare, D. Sinković. Equipment investments and growth nexus - evidence from socialist ...

Table 4. Level VAR Granger-causality test

\begin{tabular}{lcccccc}
\hline Equation & $X_{1}$ & $\begin{array}{c}X_{2} \\
\text { Equipment } \\
\text { stock }\end{array}$ & $\begin{array}{c}X_{3} \\
\text { Structures } \\
\text { stock }\end{array}$ & $\begin{array}{c}X_{4} \\
\text { Human capital } \\
\text { stock }\end{array}$ & $\begin{array}{c}X_{5} \\
\text { Labor force }\end{array}$ & $R^{2}$ \\
\hline$\left(X_{1}\right)$ & 0.911325 & 0.973709 & -0.284528 & 0.092280 & 0.000304 & 0.9928 \\
& {$[0.0000]^{* * *}$} & {$[0.0044]^{* *}$} & {$[0.4857]$} & {$[0.0358]^{* *}$} & {$[0.0763]^{*}$} & \\
\hline$\left(X_{2}\right)$ & 0.083291 & 0.888803 & -0.144126 & -0.014284 & -0.002549 & 0.8605 \\
& {$[0.1871]$} & {$[0.0002]^{* * *}$} & {$[0.3165]$} & $[0.9481]]$ & {$[0.1132]$} & \\
\hline$\left(X_{3}\right)$ & -0.041607 & 0.836397 & 0.542956 & -0.306724 & 0.000651 & 0.9168 \\
& {$[0.3832]$} & {$[0.0000]^{* * *}$} & {$[0.0000]^{* * *}$} & {$[0.0775]$} & {$[0.5874]$} & \\
\hline$\left(X_{4}\right)$ & 0.086491 & 0.101602 & 0.006314 & 0.359804 & -0.001666 & 0.8448 \\
& {$[0.1558]$} & {$[0.6017]$} & {$[0.0289]^{* *}$} & {$[0.0986]^{*}$} & {$[0.2746]$} & \\
\hline$\left(X_{5}\right)$ & 4.529422 & 37.02875 & -10.82519 & -28.71189 & 0.872207 & 0.9968 \\
& {$[0.015]^{* *}$} & {$[0.0023]^{* * *}$} & {$[0.1685]$} & {$[0.0226]^{* * *}$} & {$[0.0000]^{* * *}$} & \\
\hline
\end{tabular}

Source: Author's calculation

Causality test results show that investment-specific technological change is important for production in Croatia. Purchasing more equipment and machines is likely to boost economic growth. Causality analysis shows the existence of investment-specific technological change but then again, only for equipment (machines) and not structures (building). To support the findings from the causality analysis we provide data on the prices for machines and buildings relative to the price of consumption non-durables in Figure 3.

We can see that investment-specific technological change was indeed present in the production of machines during the observed period since the relative price of machines in comparison to the price of consumer nondurables significantly and persistently fell. This was not the case for the construction industry, where the relative price of buildings to consumer nondurables rose over the entire period. The observed relative price of buildings follows the causality results (negative relationship to output) that infer no investment-specific tech-

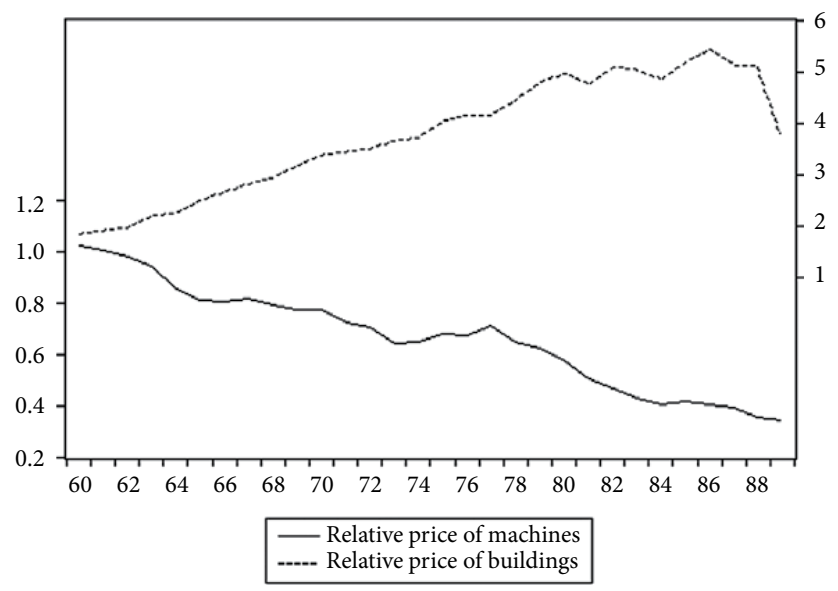

Fig. 3. Relative price for machines and buildings 1960-1989.

Source: Croatian statistical office 
nological change for structures as inputs into the production function. Another important aspect should be mentioned here, price volatility or inflation. Figure 4 show that strong price volatility was present over the full period.

Strong price volatility visible from Figure 4 was negatively correlated with investment in structures (-0.25) inferring that in a small, closed and socialist economy such as Croatia, price volatility crowded out possible investment-specific technological change for structures (increase in the marginal product of investments in structures). Similar correlation holds for the equipment-price relation with much lower intensity $(-0.08)$. Our conclusion is that investment-specific technological change for investment in structures is inversely related to strong price volatility, such as was present in Croatia. In the following, we present the results of the estimated models.

Our main findings from estimating the model (1) confirm the importance of equipment investment for growth in Croatia. As visible in Table 5, a percentage point increase in equipment investment is expected to boost output by 1.476 percentage points per year. Notice that investment in structures is also important, but the return on investment in equipment is three times the return on investment in structures. Other findings are similar to the one identified by De Long and Summers with negative impact of labor force growth to output level (as in the Solow model).

Equipment investments (gross fixed capital formation for equipment) include all expenses for fitting, transportation, customs duties and insurance. Structure investments (gross fixed capital formation for construction works) include the value of equipment built into constructions (lifts, central heating installations, etc.) and related projects. Results from the model (2) support the hypothesis that equipment investment is important for economic growth. The equipment investment - growth link is once again proven but with a much lower return on equipment investment than before. Findings from (2) show that a percentage growth in equipment investment is expected to increase production by 0.11 percentage points. The difference between shares of equipment and structure investments in this model is negligible (and much lower in comparison to the modified

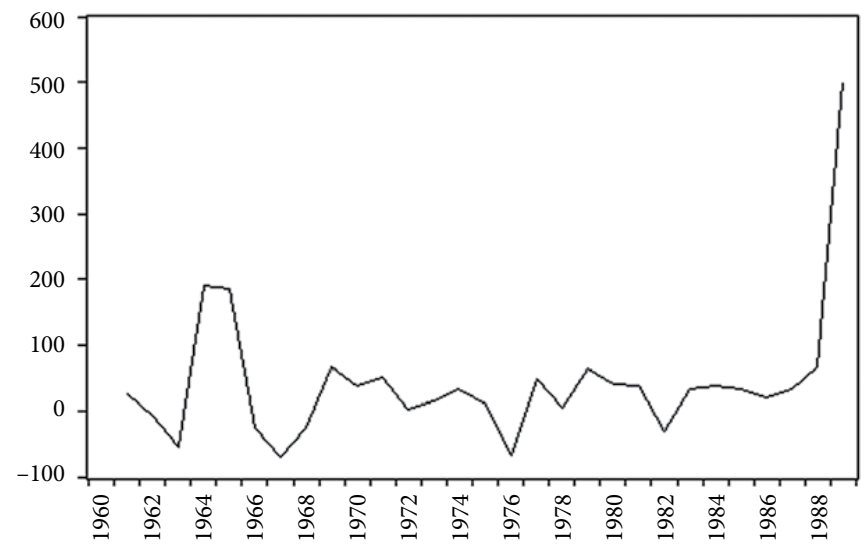

Fig. 4. Price volatility (inflation) in Croatia 1960-1989 Source: Croatian statistical office 
520 M. Škare, D. Sinković. Equipment investments and growth nexus - evidence from socialist ...

Table 5. Regression results 1960-1989 (all models)

\begin{tabular}{|c|c|c|c|c|c|}
\hline & Model (1) & Model (2) & Model (3) & Model (4) & Model (5) \\
\hline Dependent variable & $\begin{array}{l}\text { Real GDP } \\
\text { growth }\end{array}$ & $\begin{array}{c}\text { Log } \\
\text { difference } \\
\text { GDP } \\
\end{array}$ & $\begin{array}{c}\text { Log } \\
\text { difference } \\
\text { GDP/L }\end{array}$ & $\begin{array}{c}\text { Log } \\
\text { difference } \\
\text { GDP/L }\end{array}$ & $\begin{array}{c}\text { Log } \\
\text { difference } \\
\text { GDP } \\
\end{array}$ \\
\hline constant & $\begin{array}{l}-13.10235^{* * *} \\
(3.652937) \\
\end{array}$ & $\begin{array}{l}0.033624^{* * *} \\
(0.008952)\end{array}$ & $\begin{array}{l}0.015273 \\
(0.0362334) \\
\end{array}$ & $\begin{array}{l}0.012362^{\star} \\
(0.0620458) \\
\end{array}$ & -0.082282 \\
\hline $\mathrm{i}_{\mathrm{E}}$ & $\begin{array}{l}1.4760087^{\star * *} \\
(0.381355) \\
\end{array}$ & & & & \\
\hline $\mathrm{i}_{\mathrm{S}}$ & $\begin{array}{l}0.470544^{* \star *} \\
(0.261833) \\
\end{array}$ & & & & \\
\hline GAP & $\begin{array}{l}0.384638 \\
(0.172593) \\
\end{array}$ & & & & \\
\hline $\mathrm{L}$ & $\begin{array}{l}-0.367155 \\
(0.254436) \\
\end{array}$ & & & & \\
\hline$\Delta \log \mathrm{E}$ & & $\begin{array}{l}0.116051^{\star * *} \\
(0.033512)\end{array}$ & & & \\
\hline$\Delta \log S$ & & $\begin{array}{l}0.089611^{*} \\
(0.046630)\end{array}$ & & & \\
\hline$\Delta \log \mathrm{H}$ & & $\begin{array}{l}-0.039974 \\
(0.047864) \\
\end{array}$ & & & \\
\hline$\Delta \log \mathrm{L}$ & & $\begin{array}{l}0.148453 \\
(0.260015) \\
\end{array}$ & & & \\
\hline Equipment & & & $\begin{array}{l}0.104807^{\star} \\
(0.0533127) \\
\end{array}$ & & \\
\hline Structures & & & $\begin{array}{l}0.0381736 \\
(0.0398570) \\
\end{array}$ & & \\
\hline Human capital & & & $\begin{array}{l}-0.000188 \\
(0.0455601) \\
\end{array}$ & & \\
\hline$(\mathrm{n}+\mathrm{g}+\delta)$ & & & $\begin{array}{l}0.00048 \\
(0.0138264) \\
\end{array}$ & & \\
\hline$\Delta \log \mathrm{E} / \mathrm{L}$ & & & & $\begin{array}{l}0.100710^{*} \\
(0.0493213)\end{array}$ & \\
\hline$\Delta \log S / L$ & & & & $\begin{array}{l}0.0261644 \\
(0.048975)\end{array}$ & \\
\hline$\Delta \log \mathrm{H} / \mathrm{L}$ & & & & $\begin{array}{l}0.0162612 \\
(0.0372036)\end{array}$ & \\
\hline \multicolumn{6}{|l|}{$\Delta \log \mathrm{GDP}(-1)$} \\
\hline$\Delta \log \mathrm{E}(-1)$ & & & & & $\begin{array}{l}0.095685^{* *} \\
(0.04273)\end{array}$ \\
\hline$\Delta \log S(-1)$ & & & & & $\begin{array}{l}-0.217014^{\star *} \\
(0.05707)\end{array}$ \\
\hline$\Delta \log H(-1)$ & & & & & $\begin{array}{l}0.086821^{*} \\
(0.07431)\end{array}$ \\
\hline$\Delta \log \mathrm{L}(-1)$ & & & & & $\begin{array}{l}0.346976 \\
(0.23703) \\
\end{array}$ \\
\hline Trend & & & & & $\begin{array}{l}0.001870^{* * *} \\
(0.00055)\end{array}$ \\
\hline
\end{tabular}


End of Table 5

\begin{tabular}{llllll}
\hline \multirow{2}{*}{ Dependent variable } & \multicolumn{1}{c}{ Model (1) } & Model (2) & Model (3) & Model (4) & Model (5) \\
\cline { 2 - 6 } & $\begin{array}{c}\text { Real GDP } \\
\text { growth }\end{array}$ & $\begin{array}{c}\text { Log } \\
\text { difference } \\
\text { GDP }\end{array}$ & $\begin{array}{c}\text { Log } \\
\text { difference } \\
\text { GDP/L }\end{array}$ & $\begin{array}{c}\text { Log } \\
\text { difference } \\
\text { GDP/L }\end{array}$ & $\begin{array}{c}\text { Log } \\
\text { difference } \\
\text { GDP }\end{array}$ \\
\hline $\mathrm{R}^{2}$ & 0.425639 & 0.404708 & 0.223978 & 0.206847 & 0.380609 \\
\hline Normality & 0.455997 & 0.973759 & 0.88452 & 0.89507 & \\
\hline RESET & 0.2449 & 0.3757 & 0.1834 & 0.2023 & \\
\hline Restriction & 0.001438 & 0.002142 & 0.036741 & 0.032196 & \\
\hline Implied $\alpha$ & & & 0.09 & & \\
\hline Implied $\beta$ & & 0.03 & & \\
\hline Implied $\delta$ & & 0.00 & & \\
\hline
\end{tabular}

Notes: Figures in parenthesis are standard errors. 'Restriction' is the p-value for the F-test restriction (slope coefficients equal zero). 'Normality' is the p-value for the residual normality test. 'RESET' is the p-value for the Ramsey RESET test.

${ }^{* * *}$ Statistically significant a $1 \%$ level, ${ }^{* *}$ at $5 \%,{ }^{*}$ at $10 \%$ level

De Long and Summers regression). Although the technical structure of gross investments is not important model (1), equipment investment's significance for growth is supported. Human capital and labor coefficients are not statistically significant with an expected sign for labor force growth in Solow tradition but unexpected for human capital pointing to the possible simultaneity bias problem. Residuals and model diagnostics back up the estimated model. Our results do not support the Solow and augmented Solow models as in Mankiw et al. (1992) and Temple (1998) due to low $\mathrm{R}^{2}$ s and the unit root problem. Model (3) poorly fits the data with $\mathrm{R}^{2}=0.09$ and low statistical significance of individual variables. The implied capital share in income $(\alpha=0.06-0.09)$ is below values found by MRW. Structures' share (implied $\beta=0.03-0.10$ ) is still smaller than the values identified by MRW, as is human capital's share $\delta=0.03$.

In model (4) investment in equipment's effect on production is estimated at 0.10 at the $10 \%$ significance level. Other variables in the model are not statistically significant with low $\mathrm{R}^{2}=0.06$. To account for possible discrepancies from different OLS model specification and techniques, we estimate a VECM model (5) with Johansen's procedure. The estimated cointegrated vector shows that variables of equipment, structure and human capital stock enter the model significantly at the 5 and $10 \%$ levels. The estimated long-run equipment coefficient is around the values identified by Temple (1998) for developing and OECD countries. The estimated value is within the window suggested by previous models $(0.07-0.12)$. The human capital coefficient is significant at the $10 \%$ level with a positive impact of 0.08 on the production level and within expected boundaries for Croatia. The main findings from the VECM model are the importance of equipment investment for growth and the negative impact of investment in structures on output (as in Temple 1998 for OECD countries). Equipment investment registers a stronger positive impact on growth in relation to capital accumulation when used as a variable in the model. Labor's share in output is lower than expected and not statistically significant. The technical structure of investments in all models proved to be an important determinant of growth. 
522 M. Škare, D. Sinković. Equipment investments and growth nexus - evidence from socialist ...

\section{Equipment investment growth nexus in transitional Croatia (1990-2009)}

We use the same set of equations and methods (except the VECM model) to estimate the relationship between equipment investments and output in Croatia during the transition period (1990-2009). It is important to mention that Croatia is still a country in transition on the path to the EU. Here we show just the results for the transition period. Estimation results are presented in Table 6.

Table 6. Regression results 1990-2009 (all models)

\begin{tabular}{|c|c|c|c|c|}
\hline & Model (1) & Model (2) & Model (3) & Model (4) \\
\hline $\begin{array}{l}\text { Dependent } \\
\text { variable }\end{array}$ & $\begin{array}{l}\text { Real GDP } \\
\text { growth }\end{array}$ & $\begin{array}{l}\text { Log difference } \\
\text { GDP }\end{array}$ & $\begin{array}{c}\text { Log difference } \\
\text { GDP/L }\end{array}$ & $\begin{array}{c}\text { Log difference } \\
\text { GDP/L }\end{array}$ \\
\hline constant & $\begin{array}{l}\text { 3.419554 } \\
(0.382337)\end{array}$ & $\begin{array}{l}0.018924^{*} \\
(0.010206)\end{array}$ & $\begin{array}{l}0.120271 \\
(0.0660924)\end{array}$ & $\begin{array}{l}0.018240 \\
(0.010232)\end{array}$ \\
\hline$i_{E}$ & $\begin{array}{l}-0.336493 \\
(0.429490) \\
\end{array}$ & & & \\
\hline$i_{S}$ & $\begin{array}{l}0.134813 \\
(0.236803)\end{array}$ & & & \\
\hline GAP & $\begin{array}{l}.058956^{\star * *} \\
(0.088521)\end{array}$ & & & \\
\hline $\mathrm{L}$ & $\begin{array}{l}-0.077899 \\
(0.121731) \\
\end{array}$ & & & \\
\hline$\Delta \log \mathrm{E}$ & & $\begin{array}{l}0.144762^{\star *} \\
(0.053352)\end{array}$ & & \\
\hline$\Delta \log S$ & & $\begin{array}{l}0.079931 \\
(0.055100)\end{array}$ & & \\
\hline$\Delta \log \mathrm{H}$ & & $\begin{array}{l}0.146765^{\star * *} \\
(0.045356)\end{array}$ & & \\
\hline$\Delta \log \mathrm{L}$ & & $\begin{array}{l}0.210345 \\
(0.405237)\end{array}$ & & \\
\hline Equipment & & & $\begin{array}{l}0.0702635^{\star * *} \\
(0.0207935)\end{array}$ & \\
\hline Structures & & & $\begin{array}{l}0.132713^{* * *} \\
(0.0324306)\end{array}$ & \\
\hline Human capital & & & $\begin{array}{l}0.0386942 \\
(0.0514983)\end{array}$ & \\
\hline$(n+g+\delta)$ & & & $\begin{array}{l}0.0341171 \\
(0.0233145)\end{array}$ & \\
\hline$\Delta \log \mathrm{E} / \mathrm{L}$ & & & & $\begin{array}{l}0.124763^{* *} \\
(0.050126)\end{array}$ \\
\hline$\Delta \log S / L$ & & & & $\begin{array}{l}0.109262^{\star *} \\
(0.047847)\end{array}$ \\
\hline$\Delta \log \mathrm{H} / \mathrm{L}$ & & & & $\begin{array}{l}0.131345^{* * *} \\
(0.043152)\end{array}$ \\
\hline War (dummy) & $\begin{array}{l}-5.06478^{\star \star \star} \\
(0.808503)\end{array}$ & $\begin{array}{l}-0.032664 \\
(0.025633)\end{array}$ & $\begin{array}{l}-0.0102026 \\
(0.0229206)\end{array}$ & $\begin{array}{l}-0.015064 \\
(0.019601)\end{array}$ \\
\hline
\end{tabular}


End of Table 6

\begin{tabular}{lllll}
\hline \multirow{2}{*}{$\begin{array}{c}\text { Dependent } \\
\text { variable }\end{array}$} & \multicolumn{1}{c}{ Model (1) } & \multicolumn{1}{c}{ Model (2) } & Model (3) & Model (4) \\
\cline { 2 - 5 } & $\begin{array}{c}\text { Real GDP } \\
\text { growth }\end{array}$ & $\begin{array}{c}\text { Log difference } \\
\text { GDP }\end{array}$ & $\begin{array}{c}\text { Log difference } \\
\text { GDP/L }\end{array}$ & $\begin{array}{c}\text { Log difference } \\
\text { GDP/L }\end{array}$ \\
\hline $\mathrm{R}^{2}$ & 0.9352770 & 0.820785 & 0.905555 & 0.750758 \\
\hline Normality & 0.831143 & 0.804101 & 0.531993 & 0.259686 \\
\hline RESET & 0.0876 & 0.2165 & 0.8760 & 0.9166 \\
\hline Restriction & 0.00000 & 0.000051 & 0.000035 & 0.000131 \\
\hline \multicolumn{5}{l}{} \\
\hline Implied $\alpha$ & & & 0.06 & \\
\hline Implied $\beta$ & & 0.10 & \\
\hline Implied $\delta$ & & 0.03 & \\
\hline
\end{tabular}

Notes: Figures in parenthesis are standard errors. 'Restriction' is the p-value for the F-test restriction (slope coefficients equal zero). 'Normality' is the p-value for the residual normality test. 'RESET' is the p-value for the Ramsey RESET test.

${ }^{* * *}$ Statistically significant a $1 \%$ level, ${ }^{* *}$ at $5 \%,{ }^{*}$ at $10 \%$ level

In the transition period, we see a change in the technical structure of investments, with massive investments in structures such as highways, bridges, schools, and universities, particularly after 2000. As expected, the impact on growth from equipment investment remains high, with a rising share of structure investments in national income. Also, the impact of investment in structures on output growth is positive (as in the previous period) but now stronger, inferring a possible investment-specific technological change for structures. One possible explanation could be a sharp increase in the demand for housing and apartments, price stabilization and a strong rise of the construction industry. Model (1) was extremely difficult to fit on transition period data because of a strong serial correlation and heteroscedasticy problem regarding equipment and investment share in national income as well the impact of war on output. As a consequence, low statistical significance for equipment and structures is present.

Model (2) fits the data very well. Equipment investment once again is proving important for output growth even in the transition period, with the share of equipment investment in output similar to values we find for the pre-transition period. Accumulation of human capital was also an important source of growth during transition, particularly because of Bologna reforms in higher education. Model (3) shows different results, to some extent, with a statistically significant influence of structure stock on output, with a higher share in contrast to equipment stock's share in output during the transition period and specifically the one we find in the pre-transition period. Equipment stock's influence on output remains positive and significant but now lower relative to structure's share in output. The last model (4) gives us a more balanced picture of equipment and structure stock's shares in output. Both equipment and structure stocks were important for output growth in the transition period accompanied by human capital with the highest impact on output. This result confirms the importance of equipment investment for growth in Croatia during the transition. Moreover, it shows the increasing importance of structure investments and human capital accumulation after 1990. 


\section{Conclusions}

In this paper, we suggest that the augmented Solow model with human capital, equipment and structure stocks can explain output growth in Croatia. Results of the study prove the importance of equipment investment for economic growth in Croatia both in pre-transition and transition period. Our major finding is that technical structure of investments is important in explaining growth and should be accounted for in growth models. The same applies to human capital, which should be measured differently from standard procedures (years of schooling, enrolment rates and ect.) as suggested by Škare (2001). We believe that growth models could do a better job in international comparisons if investment in technical structure and estimated human capital stock are included because they fit the data more accurately. As for Croatia, we find evidence of an extensive growth pattern as in other former socialist countries. Growth was generated mainly through input accumulation and marginally through TFP growth. This changed, to some extent, after 1990, still the diminishing returns to scale remain persistent. Besides the war damages, this is the explanation for slow Croatia's convergence to EU growth. Another important aspect of the study is that the importance of capital for growth changes significantly if investment's share of GDP is used as a proxy for capital. We believe a better fit of data relating to capital's share in income assessment can be obtained by using estimated capital stock or real data on capital stock. Diminishing returns to capital and human capital back up our hypothesis that the structure of investment is more important than how much money is invested. Croatia's case shows that poor technical structure of investments (large investments in structure) and in university school campuses will result in diminishing return to scale unless accompanied by more investments in equipment and knowledge (libraries, computer labs, distance learning and other forms of learning equipment).

The empirical results of the relationships between disaggregated components of investment and economic growth carried out by De Long and Summers (1991, 1992, 1993, 1994) and Temple (1998) find a strong basis in the evidence of Croatia. This paper's results suggest that equipment investment has a special role in boosting GDP growth, since the equipment investments-growth link appears to be stronger than the structure investment-growth link for both pre-transition and transition periods. We also found a strong positive relationship between human capital and GDP growth for the transition period that is consistent with previous work of Škare (2001). Various tests confirm the consistency and robustness of the regression results. Bearing in mind that Croatia is a country in transition whose main investment focus for many years was on structures (highways, tourism sector infrastructure, residential buildings and so on), alongside insufficient human capital investment, it is no wonder that the economic future in Croatia looks problematic. Furthermore, since 2000 Croatia went through a huge lending boom in which Croatian private commercial banks mostly promoted household consumption spending instead of investment spending. Rising from very low levels in 1999, household loans grew almost six times by 2008 reaching 35 percent of the GDP - the highest level in all the transitional countries. Poor allocation of the local savings did not ensure channelling adequate level of the financial resources to the SMEs and industrial sectors, the two main engines of innovation, technology transfer and economic growth. The current composition of investments certainly does stimulate GDP 
levels, but only in the short term with no meaningful long-term economic impact. The fact that most of those investments, especially the government investments, are being financed by external borrowings could actually swamp most foreseeable benefits arising for the Croatian economy. This suggests that additional research on this topic is urgently required. This study is our humble contribution to the international studies on growth differences and nature of growth in transitional countries.

\section{Acknowledgment}

We are grateful two anonoymous referees for their helpful comments and suggestions in efforts to improve the article.

\section{References}

Auerbach, A. J.; Hasset, K. A.; Oliner, S. D. 1993. Reassessing social returns to equipment investments, NBER Working Paper No. 4405/93.

Barro, R. J. 1991. Economic growth in a cross section of countries, The Quarterly Journal of Economics 106(2): 407-443. http://dx.doi.org/10.2307/2937943

Benhabib, J.; Spiegel, M. M. 1994. The role of human capital in economic development: evidence from aggregate cross country data, Journal of Monetary Economics 34: 143-173. http://dx.doi.org/10.1016/0304-3932(94)90047-7

Benhabib, J.; Spiegel, M. M. 2005. Human Capital and Technology Diffusion: Handbook of Economic Growth. Vol. 1, 935-966.

Bloomfield, P. 1976. Fourier Analysis of Time Series. New York: John Wiley and Sons.

Blomstrom, M.; Lipsey, R. E.; Zejan, M. 1993. Is fixed investment the key to economic growth?, NBER Working Paper No. 4436. National Bureau of Economic Research, Cambridge, MA.

Croatian National Bank 2009. Statistical Publication.

Del Rio, F. 2010. Investment-specific technical progress, capital obsolescence and job creation, Labour Economics 17(1): 248-257. http://dx.doi.org/10.1016/j.labeco.2009.09.005

De Long, J. B.; Summers, L. H. 1991. Equipment investments and economic growth, Quarterly Journal of Economics 106: 445-502. http://dx.doi.org/10.2307/2937944

De Long, J. B.; Summers, L. H. 1992. Equipment investments and economic growth: how strong is the nexus?, Brookings Papers on Economic Activity, 157-199. http://dx.doi.org/10.2307/2534583

De Long, J. B.; Summers, L. H. 1993. How strongly do developing countries benefit from equipment investments, Journal of Monetary Economics 32:395-415. http://dx.doi.org/10.1016/0304-3932(93)90024-A

De Long, J. B.; Summers, L. H. 1994. Equipment investments and economic growth: reply, Quarterly Journal of Economics 109: 803-807. http://dx.doi.org/10.2307/2118423

Ding, S.; Knight, J. 2009. Can the augmented Solow model explain China's remarkable economic growth? A cross country panel data analysis, Journal of Comparative Economics 37: 432-452. http://dx.doi.org/10.1016/j.jce.2009.04.006

Dolenc, P. 2010. Privatization in a Post-Communist economy: it seems there are no macroeconomic effects, Ekonomska istrazivanja - Economic research 23(1): 60-72.

Dolenc, P.; Laporšek, S.; Šeparović, A. 2011. Does labour taxation affect unemployment? Croatia worker in international perspective, Ekonomska istrazivanja - Economic research 24(3): 86-101.

Dulleck, U.; Foster, N. 2008. Imported equipment, human capital and economic growth in developing countries, Economic Analysis and Policy 38(2): 233-250. 
Engle, R. F.; Granger, C. W. J. 1987. Cointegration and error correction: representation, estimation, testing, Econometrica 55: 1057-1072. http://dx.doi.org/10.2307/1913236

Field, A. J. 2007. The equipment hypothesis and us economic growth, Explorations in Economic History 44(1): 43-58. http://dx.doi.org/10.1016/j.eeh.2005.09.002

Geary, R. C. 1958. A note on comparisons of exchange rates and purchasing power between countries, Journal of the Royal Statistical Society 121(1): 97-99. http://dx.doi.org/10.2307/2342991

Greenwood, J.; Hercowitz, Z.; Krusell, P. 1996. Long-run implications of investments-specific technological change, Working Paper No. 420/96. Rochester Center for Economic Research.

Greenwood, J.; Krusell, P. 2007. Growth accounting with investment-specific technological progress: a discussion of two approaches, Journal of Monetary Economics 54(4): 1300-1310. http://dx.doi.org/10.1016/j.jmoneco.2006.02.008

Hendricks, L. 2000. Equipment investments and growth in developing countries, Journal of Development Economics 61: 335-364. http://dx.doi.org/10.1016/S0304-3878(00)00060-2

Iacobucci, A. 2003. Spectral analysis for economic time series, OFCE Working Paper No. 2003-07.

Jones, C. I. 1994. Economic growth and relative price of capital, Journal of Monetary Economics 34: 359-382. http://dx.doi.org/10.1016/0304-3932(94)90024-8

Khamis, S. 1972. A new system of index numbers for national and international purposes, Journal of the Royal Statistical-Society, Series A, 135.

Levine, R.; Renelt, D. 1992. A sensitivity analysis of cross-country growth regressions, American Economic Review 82(4): 942-963.

Maddison, A. 2001. The World Economy: Historical Statistics. OECD.

Maddison, A. 2003. The World Economy: a Millennial Perspective. OECD.

Mankiw, N. G.; Romer, D.; Weil, D. N. 1992. A contribution to the empirics of economic growth, Quarterly Journal of Economics 107: 407-437. http://dx.doi.org/10.2307/2118477

Solow, R. M. 1957. Technical change and the aggregate production function, Review of Economics and Statistics 39: 312-320. http://dx.doi.org/10.2307/1926047

Sufian, F. 2010. Assessing the impact of financial sector restructuring on bank performance in a small developing economy, Ekonomska istrazivanja - Economic research 23(2): 11-34.

Summers, L. 1990. What is the social rate of return to capital investment?, in Diamond, P. (Ed.). Essays in Honor of Robert Solow. Cambridge, MA: M.I.T. Press.

Škare, M. 2001. Human capital as a source of growth - myth or reality, in Ekonomski Pregled. Zagreb, 189-206.

Škare, M.; Sinković, D. 2007. Equipment Investments as a main driving force of economic growth in Republic of Croatia, in 4th International Conference proceedings Global Challenges for Competitiveness: Business and Government Perspective. Department of Economics and Tourism 'Dr. Mijo Mirkovic', Juraj Dobrila University of Pula, 121-133.

Temple, J. R. W. 1998. Equipment Investments and the Solow Model. Oxford Economic Papers. http://dx.doi.org/10.1093/oxfordjournals.oep.a028635

Temple, J. R. W.; Voth, H. 1996. Human capital, equipment investments and industrialization, European Economic Review 2(7): 1343-1362.

Tridico, P. 2007. Institutions, human development and economic growth, The European Journal of Development Research 19(4): 569-593. http://dx.doi.org/10.1080/09578810701667607

Tvaronavičius, V.; Tvaronavičienè, M. 2008. Role of fixed investments in economic growth of country: Lithuania in European context, Journal of Business Economics and Management 9(1): 57-64. http://dx.doi.org/10.3846/1611-1699.2008.9.57-64

Tvaronavičienè, M.; Grybaite, V.; Korsakienè, R. 2008. Foreign capital destinations: Baltic States versus India, Journal of Business Economics and Management 9(3): 227-234.

http://dx.doi.org/10.3846/1611-1699.2008.9.227-234 
Tvaronavičienè, M.; Grybaite, V. 2007. Impact of FDI on Lithuanian economy: insight into development of main economic activities, Journal of Business Economics and Management 8(4): 285-290.

Tvaronavičiene, M. 2006. Investment driving forces afecting Lithuanian economic growth, Journal of Business Economics and Management 7(2): 69-76.

Yilmaz, R.; Koyuncu, C. 2010. Foreign bank participation and banking crises in transition economies, Ekonomska istrazivanja - Economic research 23(1): 15-29.

\section{APPENDIX}

Table A1. Augmented Dickey-Fuller and Phillips-Perron Unit Root Test

\begin{tabular}{|c|c|c|c|c|c|c|c|}
\hline \multirow[b]{2}{*}{ Variables } & \multicolumn{3}{|c|}{ Level } & \multicolumn{4}{|c|}{ First differences } \\
\hline & Intercept & $\begin{array}{l}\text { Intercept and } \\
\text { trend }\end{array}$ & None & \multicolumn{2}{|c|}{ Intercept } & $\begin{array}{l}\text { Intercept and } \\
\text { trend }\end{array}$ & None \\
\hline GDP & -1.214 & -0.258 & 3.968 & \multicolumn{2}{|c|}{$-4.666^{\star \star \star}$} & $-5.998^{\star \star \star}$ & $-2.905^{\star \star \star}$ \\
\hline Capital & 2.7344 & -2.914 & 10.947 & \multicolumn{2}{|c|}{$-4.356^{\star \star \star}$} & $-5.375^{\star \star \star}$ & -1.437 \\
\hline Human capital & -1.953 & -2.393 & 0.327 & \multicolumn{2}{|c|}{$-5.704^{\star * \star}$} & $-6.807^{\star * *}$ & $-4.936^{\star * *}$ \\
\hline Labor & -0.145 & -1.129 & 5.965 & \multicolumn{2}{|c|}{$-3.903^{* * *}$} & $-3.777^{\star * *}$ & $-3.073^{\star * *}$ \\
\hline $\begin{array}{l}\text { Equipment } \\
\text { investments }\end{array}$ & -1.457 & -0.563 & -0.200 & \multicolumn{2}{|c|}{$-5.696^{\star * *}$} & $-6.270^{\star \star *}$ & $-5.736^{\star * \star}$ \\
\hline Structures & -1.8594 & -1.234 & -0.555 & \multicolumn{2}{|c|}{$-3.431^{\star \star \star}$} & $-3.739^{\star * *}$ & $-3.513^{\star * \star}$ \\
\hline Phillips-Perron & \multicolumn{2}{|c|}{ Level } & \multicolumn{4}{|c|}{ First differences } & \multirow[t]{2}{*}{ Lag selection } \\
\hline Variables & Intercept & $\begin{array}{l}\text { Intercept } \\
\text { and trend }\end{array}$ & \multicolumn{2}{|c|}{ Intercept } & \multicolumn{2}{|c|}{$\begin{array}{l}\text { Intercept } \\
\text { and trend }\end{array}$} & \\
\hline GDP & -1.170 & -0.511 & \multicolumn{2}{|c|}{$-4.775^{\star \star \star}$} & \multicolumn{2}{|c|}{$-6.116^{* * *}$} & 1 \\
\hline Capital & 2.089 & -2.821 & \multicolumn{2}{|c|}{$-4.537^{\star \star \star}$} & \multicolumn{2}{|c|}{$-5.381^{\star * *}$} & 1 \\
\hline Human capital & -1.935 & -2.308 & \multicolumn{2}{|c|}{$-5.852^{\star * \star}$} & \multicolumn{2}{|c|}{$-6.731^{\star \star *}$} & 1 \\
\hline Labor & -0.267 & -1.548 & \multicolumn{2}{|c|}{$-3.934^{\star * *}$} & \multicolumn{2}{|c|}{$-3.817^{\star \star}$} & 1 \\
\hline $\begin{array}{l}\text { Equipment } \\
\text { investments }\end{array}$ & -1.536 & -0.644 & \multicolumn{2}{|c|}{$-5.694^{\star * *}$} & \multicolumn{2}{|c|}{$-6.301^{* * *}$} & 1 \\
\hline Structures & -1.664 & -0.608 & \multicolumn{2}{|c|}{$-3.446^{\star * *}$} & \multicolumn{2}{|c|}{$-3.705^{\star \star \star}$} & 1 \\
\hline
\end{tabular}

Note: ${ }^{*}, * *{ }^{* *}$ denote statistical significance at the $10 \%, 5 \%$ and $1 \%$ levels

Source: Author's calculation

Table A2. Johansen test statistics for cointegration between $\log (\mathrm{Y}), \log (\mathrm{E}), \log (\mathrm{S}), \log (\mathrm{Labor}), \log (\mathrm{H})$

\begin{tabular}{lccccc}
$\begin{array}{l}\text { Selected }\left(0.05 \text { level }^{*}\right) \\
\text { Number of Cointegrating Relations } \\
\text { by Model }\end{array}$ & & & & & \\
\hline Data Trend: & None & None & Linear & Linear & Quadratic \\
Test Type & No Intercept & Intercept & Intercept & Intercept & Intercept \\
& No Trend & No Trend & No Trend & Trend & Trend \\
Trace & 3 & 3 & 1 & 1 & 1 \\
Max-Eig & 2 & 0 & 0 & 0 & 0 \\
\hline
\end{tabular}

Source: Author's calculation 
Table A3. VAR Optimal Lag Selection

\begin{tabular}{|c|c|c|c|c|c|c|}
\hline \multicolumn{7}{|c|}{ VAR Lag Order Selection Criteria } \\
\hline \multicolumn{7}{|c|}{$\begin{array}{l}\text { Endogenous variables: GDP EQUIPMENT ST } \\
\text { Exogenous variables: C } \\
\text { Date: } 04 / 01 / 10 \text { Time: } 23: 25 \\
\text { Sample: } 19601989 \\
\text { Included observations: } 26\end{array}$} \\
\hline Lag & $\log \mathrm{L}$ & LR & FPE & AIC & SC & HQ \\
\hline 0 & -1161.376 & NA & $6.36 \mathrm{e}+32$ & 89.72121 & 89.96315 & 89.79088 \\
\hline 1 & -1022.616 & $213.4759^{\star}$ & $1.05 e+29$ & 80.97049 & $82.42214^{*}$ & 81.38851 \\
\hline 2 & -996.2516 & 30.42093 & $1.20 \mathrm{e}+29$ & 80.86551 & 83.52686 & 81.63188 \\
\hline 3 & -968.2978 & 21.50292 & $2.00 \mathrm{e}+29$ & 80.63829 & 84.50936 & 81.75302 \\
\hline 4 & -902.7942 & 25.19370 & $7.30 \mathrm{e}+28^{*}$ & $77.52263^{*}$ & 82.60340 & $78.98571^{*}$ \\
\hline $\begin{array}{l}{ }^{*} \text { ind } \\
\text { LR } \\
\text { FP } \\
\text { AI } \\
\text { SC } \\
\text { HC }\end{array}$ & $\begin{array}{l}\text { es lag order s } \\
\text { uential mod } \\
\text { nal predictio } \\
\text { kaike inform } \\
\text { iwarz inform } \\
\text { annan-Quin }\end{array}$ & $\begin{array}{l}\text { Led by the } \mathrm{c} \text {. } \\
\text { LR test stat } \\
\text { ror } \\
\text { criterion } \\
\text { criterion } \\
\text { ormation } \mathrm{c}\end{array}$ & $\begin{array}{l}\text { ion } \\
\text { (each test a } \\
\text { ion }\end{array}$ & o level) & & \\
\hline
\end{tabular}

Source: Author's calculation

Marinko ŠKARE. Professor of Economics, Economic Research Journal Editor in Chief, Member of Editorial Board of several international journals, Department Economics and Tourism "Dr Mijo Mirković" in Pula, Juraj Dobrila University of Pula. He served as Assistant Dean for Education, Faculty of Economics \& Tourism, Pula, Assistant Dean for International Cooperation, Faculty of Economics \& Tourism, Pula, Main and Team Researcher on several scientific projects, Former Dean of the Faculty of Economics \& Tourism, Pula and Former Vice President for International Cooperation, Juraj Dobrila University of Pula. He has published several books and a large number of scientific papers on the subject of economic growth, welfare economics and poverty, human capital, economics in transition, economic philosophy and monetary economics. He is member of the American Economic Association, Royal Economic Society, Economic History Association, Economic History Society, and Association for Comparative Economic Studies.

Dean SINKOVIĆ is Senior Assistant at Juraj Dobrila University of Pula (Department of Economics and Tourism) and Visiting Professor of Marketing Management at Albstadt-Singmaringern Hochshule (Germany). He holds an MBA degree in marketing and finance from University of Illinois at Chicago, Master of Science and $\mathrm{PhD}$ in Economics from University of Pula. His academic background is in teaching and research on economic growth, investments as well as financial and policy development. He is an author and co-author of several research papers and books and has been actively involved in many local development projects in Istria County. He was an A+ student as an undergraduate student. In 2003 he was awarded a membership to honour society to collegiate schools of business Beta Gamma Sigma in recognition for high scholastic achievements (University of Illinois). He is also a member of Who's Who Historical Society of Professional Management since 2003 (University of Illinois). 